\title{
Predicting the consequences of anthropogenic disturbance: large-scale effects of loss of canopy algae on rocky shores
}

\author{
L. Benedetti-Cecchi ${ }^{1 *}$, F. Pannacciulli ${ }^{2}$, F. Bulleri ${ }^{1}$, P. S. Moschella ${ }^{2}$, L. Airoldi ${ }^{1,3}$, \\ G. Relini ${ }^{2}$, F. Cinelli ${ }^{1}$ \\ ${ }^{1}$ Dipartimento di Scienze dell'Uomo e dell'Ambiente, Via A. Volta 6, 56126 Pisa, Italy \\ ${ }^{2}$ Laboratorio di Biologia Marina ed Ecologia Animale - Istituto di Zoologia, Università di Genova, Via Balbi 5 , \\ 16126 Genova, Italy \\ ${ }^{3}$ Scienze Ambientali, Università di Bologna, Via Tombesi dall'Ova 55, 48100 Ravenna, Italy
}

\begin{abstract}
Anthropogenic disturbances affect natural populations and assemblages by interacting with fundamental ecological processes. Field experiments simulating the effects of human activities at the appropriate spatial and temporal scales are useful to understand these interactions and eventually to predict their ecological consequences. In the Mediterranean, low-shore habitats of rocky coasts are often dominated by canopy algae Cystoseira spp., but these species are frequently replaced by assemblages of turf-forming algae and mussel beds. We propose that anthropogenic disturbance is the proximate cause of loss of Cystoseira in the Mediterranean, and that the disappearance of canopy algae causes an increase in cover of turf-forming species in disturbed habitats. Two hypotheses were investigated to test this proposition: (1) canopy algae will be dominant in relatively pristine habitats while turf-forming algae will be more abundant in urban areas, and (2) removal of canopy algae in unpolluted areas will result in the development of assemblages similar to those found in urban areas. We tested the first hypothesis by comparing patterns in abundance of Cystoseira and turf-forming algae at a number of locations in urban areas and in areas far from distinct sources of anthropogenic disturbance in the northwest Mediterranean. The second hypothesis was tested by conducting a largescale manipulative experiment, involving the experimental removal of Cystoseira and several spatial and temporal repetitions of the manipulation. Turf-forming algae were always dominant in urban areas where Cystoseira was nearly absent. In contrast, canopy algae often dominated rocky shores in relatively pristine areas of the northwest Mediterranean. The removal of Cystoseira generally caused an increase in the percentage cover of turf-forming algae and a decrease in the abundance of invertebrates. These changes were already evident 4 mo after manipulation and were consistent at the spatial and temporal scales examined in the study. Assemblages in cleared patches were qualitatively similar to those occurring where Cystoseira was naturally absent, but quantitative differences in the relative abundance of several taxa were still evident by the end of the study. These results support a causeeffect relationship between anthropogenic disturbance and loss of Cystoseira in the northwest Mediterranean and allow for quantitative predictions of the indirect consequences of disturbing canopy algae for the whole understory assemblage. Management options aimed at conserving these plants should simultaneously preserve other components of the assemblage.
\end{abstract}

KEY WORDS: Anthropogenic disturbance $\cdot$ Canopy algae $\cdot$ Cystoseira $\cdot$ Habitat formers $\cdot$ Indirect effects $\cdot$ Large-scale experiments $\cdot$ Prediction $\cdot$ Rocky shores $\cdot$ Turf-forming algae

\section{INTRODUCTION}

Anthropogenic disturbances, defined as any potential source of stress to natural populations and assem-

*E-mail: bencecc@discat.unipi.it blages due to human activities, often interact with ecological processes at varying scales in space and time altering numbers of species and their relative abundances through direct and indirect effects (Addessi 1994, Keough \& Quinn 1998, Lindberg et al. 1998). Assessing, interpreting and predicting these changes

() Inter-Research 2001 
are essential for identifying appropriate strategies for environmental management and conservation.

The detection of environmental impact relies on adequate descriptions of natural patterns of distribution and abundance of species (e.g. Underwood 1992, 1994, Osenberg et al. 1994, Benedetti-Cecchi in press). The interpretation and prediction of effects caused by human intrusions into the environment require a basic understanding of the ecological processes that are affected by these activities, and knowledge of the consequences of altering these processes (Lubchenco et al. 1991, Peterson 1993). Cause-effect relationships need to be established between anthropogenic disturbance and changes in natural assemblages, and this requires experimentation. A general problem in using experiments to assess the effects of human disturbances is that impacts often occur at such large spatial and sometimes temporal scales that logistic constraints can make experimentation problematic (Carpenter 1990). However, large-scale manipulations can be conducted in some environments and for some types of disturbance. Examples are available for a variety of terrestrial and aquatic systems (Likens 1985, Schindler 1987, Carpenter et al. 1995), although replication at those scales is often difficult if not impossible.

Some anthropogenic disturbances occur at smaller scales and are more tractable experimentally. For example, an experimental investigation on the effects of human trampling on rocky shores can be done at scales that guarantee adequate replication of treatments in space and time (e.g. Keough \& Quinn 1998). In addition to providing mechanistic explanations for the effects of anthropogenic disturbances and estimates of the magnitude of these effects, experimental manipulations can also identify the circumstances under which impacts can be expected to be large or, alternatively, negligible. Hence, process-oriented experimental research (sensu Peterson 1993, Underwood 1995) provides a basis for predicting the consequences of environmental disturbances in natural assemblages.

A suite of human disturbances (e.g. industrial and urban wastes) are known to cause a variety of impacts to coastal assemblages, including changes to the spatial and temporal patterns of distribution of organisms (Littler \& Murray 1975, Fairweather 1990, Schroeter et al. 1993, Adessi 1994, Chapman et al. 1995, Roberts et al. 1998), reduction in species diversity (Borowitzka 1972) and large-scale changes in the physical and biological structure of natural habitats (Clark 1996, Schmitt \& Osenberg 1996). An example of such changes is the decline in cover of canopy algae observed in the last 30 yr by many authors from different parts of the world (Littler \& Murray 1975, Thom \& Widdowson 1978, Thom 1980, Seapy \& Littler 1982, Hoffman et al. 1988, Rodríguez-Prieto \& Polo 1996, Vogt \&
Schramm 1991). This pattern appears to be paralleled by a trend of increasing abundance of turf-forming algae (Airoldi et al. 1995 and references therein), which, once established, appear to inhibit invasion of canopies and other organisms (Sousa et al. 1981, Airoldi 1998). Canopy algae are involved in important ecological processes such as nutrient cycling, and their loss may have important ecological and economical consequences, like the decline of local fisheries due to the reduction in overall productivity of marine coastal assemblages (Worm et al. 1999, 2000 and references therein).

Canopy algae of the genus Cystoseira are characteristic of low-shore habitats on some rocky coasts in the Mediterranean. These algae are considered important habitat formers (or ecological engineers, sensu Jones et al. 1994), providing shade and shelter for a diversified assemblage of animals and plants (Feldmann 1937, Boudouresque 1971). Alternatively, low-shore habitats are characterised by stands of turf-forming algae and mussel beds in the northwest Mediterranean (Benedetti-Cecchi \& Cinelli 1994, Benedetti-Cecchi et al. 1996a, Airoldi pers. obs.). Some evidence suggests that algae of the genus Cystoseira are highly sensitive to anthropogenic disturbances and tend to disappear from urban areas (Bellan-Santini 1968, Hoffman et al. 1988, Rodríguez-Prieto and Polo 1996, Ballesteros et al. 1998). Although the mechanisms responsible for these effects are not fully understood, stress might result from the combined effects of heavy loads of nutrients, toxicants and sediments in urban areas (e.g. Diez et al. 1999).

We propose that anthropogenic disturbance, largely in the form of urbanisation, is the proximate cause of loss of Cystoseira in the Mediterranean and that the disappearance of canopy algae causes an increase in cover of turf-forming species in disturbed habitats. This proposition leads to 2 testable hypotheses: (1) canopy algae will be dominant in relatively pristine habitats while turf-forming algae will be more abundant in urban areas, and (2) removal of canopy algae in unpolluted areas will result in the development of assemblages similar to those found in urban areas. We tested the first hypothesis by comparing patterns in abundance of Cystoseira and turf-forming algae at a number of locations in urban areas and in areas far from distinct sources of anthropogenic disturbance. A large-scale manipulative experiment, involving the experimental removal of Cystoseira and several spatial and temporal repetitions of the manipulation, was done to test the second hypothesis.

Because the effects of anthropogenic disturbance on Cystoseira were expected to occur at the scale of the landscape $(100 \mathrm{~s}$ of $\mathrm{km})$, we tested whether the removal of Cystoseira caused changes to understory as- 
semblages over and above natural variation at that particular scale. We also tested whether these effects were consistent across different temporal scales. Hence, this study addressed 3 major issues. First, it sought to identify relationships between anthropogenic disturbance and changes in low-shore assemblages in the northwest Mediterranean. Second, it provided an estimate of the magnitude of this relationship. Third, it tested whether these effects are a predictable feature of low-shore assemblages, irrespective of spatial or temporal scale. Addressing these questions is central to the development of predictive models that assess environmental impacts on low-shore assemblages in the Mediterranean.

\section{MATERIALS AND METHODS}

The study system. This study was conducted between June 1996 and December 1999 at several locations in the northwest Mediterranean (Fig. 1, Table 1). These were chosen to represent the types of assemblages commonly found in low-shore habitats, and included shores with extensive canopies of brown algae of the genus Cystoseira (clumps 30 to $40 \mathrm{~cm}$ in height with a canopy 20 to $30 \mathrm{~cm}$ in diameter), mainly the Cystoseira amentacea Bory var. stricta Montagne, and shores characterised either by stands of turf-forming algae or mussel beds (Mytilus galloprovincialis Lamark).

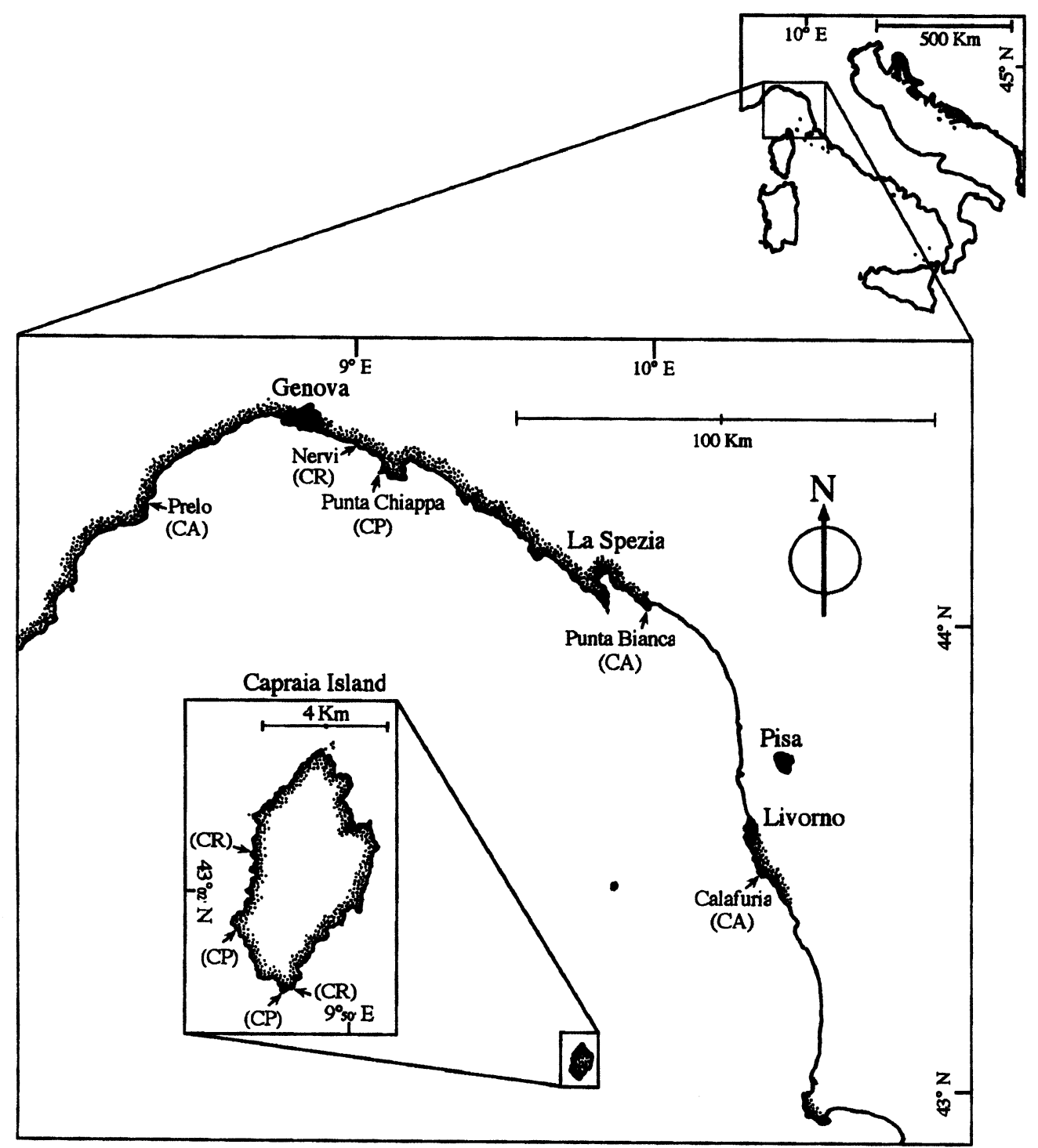

Fig. 1. Map of experimental area indicating shores (CR) where Cystoseira was removed, (CP) where Cystoseira was present, and (CA) where canopy algae was lacking. Stippled areas indicate rocky shores; larger black areas indicate major urban centers. Locations used to compare abundance of Cystoseira and turf-forming algae in relatively pristine and urban areas indicated in Table 1 
Table 1. Hierarchical sampling design used to compare patterns in abundance of Cystoseira and turf-forming algae in relatively pristine and urban areas of the northwest Mediterranean. Numbers in parentheses indicate extent of spatial scales sampled (location, shore, site), or resolution of sampling unit (replicate)

\begin{tabular}{|lllllll|}
\hline Habitat & \multicolumn{1}{c}{ Location } & Geographic position & Sampling date & Shore & Site & Replicates \\
\hline Pristine & Capraia $(4 \mathrm{~km})$ & $43^{\circ} 02^{\prime} \mathrm{N}, 9^{\circ} 50^{\prime} \mathrm{E}$ & May 1998 & $6(25-30 \mathrm{~m})$ & $2(2-3 \mathrm{~m})$ & $3(15 \times 15 \mathrm{~cm})$ \\
& Argentario $(4 \mathrm{~km})$ & $42^{\circ} 23^{\prime} \mathrm{N}, 11^{\circ} 10^{\prime} \mathrm{E}$ & Jun 1998 & $4(30-50 \mathrm{~m})$ & $\ldots \ldots$ & $8(20 \times 20 \mathrm{~cm})$ \\
& Giannutri $(4 \mathrm{~km})$ & $42^{\circ} 15^{\prime} \mathrm{N}, 11^{\circ} 65^{\prime} \mathrm{E}$ & Dec 1999 & $6(30-50 \mathrm{~m})$ & $2(3-4 \mathrm{~m})$ & $5(20 \times 20 \mathrm{~cm})$ \\
\multirow{3}{*}{ Urban } & Punta Bianca $(4 \mathrm{~km})$ & $44^{\circ} 05^{\prime} \mathrm{N}, 10^{\circ} 0^{\prime} \mathrm{E}$ & May 1998 & $6(25-30 \mathrm{~m})$ & $2(3-4 \mathrm{~m})$ & $3(15 \times 15 \mathrm{~cm})$ \\
& Calafuria $(2 \mathrm{~km})$ & $43^{\circ} 30^{\prime} \mathrm{N}, 10^{\circ} 20^{\prime} \mathrm{E}$ & Jun 1998 & $6(25-30 \mathrm{~m})$ & $2(3-4 \mathrm{~m})$ & $3(15 \times 15 \mathrm{~cm})$ \\
& Elba $(4 \mathrm{~km})$ & $42^{\circ} 51^{\prime} \mathrm{N}, 10^{\circ} 25^{\prime} \mathrm{E}$ & Nov 1999 & $5(30-50 \mathrm{~m})$ & $2(3-4 \mathrm{~m})$ & $5(20 \times 20 \mathrm{~cm})$ \\
& & & & & & \\
\hline
\end{tabular}

Several species of filamentous and coarsely branched algae and a diversified assemblage of invertebrates were associated with Cystoseira. Invertebrates included actinians, ascidians, barnacles (Balanus spp.), bryozoans, hydrozoans and sponges. Mussels were present in the understory of Cystoseira on some shores. Another brown alga, the turf-forming Cystoseira compressa (Esper) Gerloff and Nizzamuddin, was present at heights on the shore above or below those occupied by canopy algae.

Assemblages of turf-forming algae included the geniculate coralline algae Corallina elongata Ellis et Solander and Haliptilon virgatum (Zanardini) Garbary and Johansen, the coarsely branched algae Laurencia spp. (Hudson) Lamouroux, Chondria spp. (De Notaris) De Toni and Gastroclonium clavatum (Roth) Ardissone, and several species of filamentous algae.

Important grazers such as sea urchins were nearly absent on all shores in these shallow habitats, although present at greater depths in several areas. Limpets were occasionally present in patches of substratum lacking other organisms or over encrusting coralline algae.

Sampling design. Patterns in abundance of Cystoseira and turf-forming algae were compared in relatively pristine (hereafter simply 'pristine') and urban areas in the northwest Mediterranean, using a hierarchical sampling design (Table 1). Pristine locations were at least $5 \mathrm{~km}$ away from distinct sources of anthropogenic disturbance and were not accessible from land. In contrast, rocky shores in urban areas were close (within $1 \mathrm{~km}$ ) to cities, commercial harbours or other distinct sources of anthropogenic disturbance, and had direct access from land. These locations were commonly visited by many tourists during the summer (authors' pers. obs.). According to these criteria, we were able to identify 3 locations in pristine habitats and 3 locations in urban areas (Table 1). Capraia, Giannutri and Elba are islands, while Argentario, Livorno and Punta Bianca are mainland sites. Capraia and Giannutri were declared nature reserves in 1991. These locations were comparable in terms of geo- graphical orientation, exposure to waves and general topography of the substratum.

Although this sampling programme was initiated after the start of the experimental clearing of Cystoseira (see below), and included some of the locations used in the experiment, selection of the study areas was not influenced by prior knowledge of the structure and composition of assemblages: different sites were used for both the sampling and experimental programmes, when these were done at the same location. The locations examined here were chosen to represent extensive areas of rocky coast for each of the 2 conditions (pristine and urban rocky shores), and to meet the logistical requirement of accessibility from land or by boat.

In order to obtain representative estimates of abundance of Cystoseira and turf-forming algae, several sites were randomly selected at each location. This was done by first identifying all the possible sites at each location, then extracting the desired number of sites (see Table 1) by means of a table of random digits. Using a similar procedure, patches were established within sites and random quadrats sampled within patches (quadrats were randomised within sites at Argentario). The percentage cover of Cystoseira and turf-forming algae was estimated using a plastic frame divided into 25 sub-quadrats of $4 \times 4$ or $3 \times 3 \mathrm{~cm}$, depending on the size of the sampling unit (Table 1), and a score from 0 to $4 \%$ was given to each taxon in each sub-quadrat after visual inspection. Final cover was obtained by summing over the 25 small quadrats. This procedure was more rapid than the classical point-intercept technique, with no loss in terms of precision and accuracy of estimates (Dethier et al. 1993, Benedetti-Cecchi et al. 1996b).

Experimental design. When this experiment was first planned, quantitative data on the distribution of Cystoseira and turf-forming algae in relation to anthropogenic disturbance were not yet available (see above). Indeed, the study was initially motivated by qualitative observations made by the authors on the distribution of turf-forming and canopy algae in the 
northwest Mediterranean, and by data from the published literature documenting the sensitivity of Cystoseira to anthropogenic disturbance (op. cit.).

The experiment included 9 shores (Fig. 1): 6 shores had canopies, 2 were mostly characterised by turfforming algae with sparse cover of mussels, and 1 was dominated by mussels. The effects of Cystoseira were examined by removing these plants from patches of substratum on 2 shores (chosen at random) of the island of Capraia and on 1 of the 2 shores supporting canopy algae of the mainland (chosen at random, Fig. 1). Both the holdfast and the erect fronds of Cystoseira were removed using hammer and chisel, a paint scraper or a knife. The epiphytes of the bases of Cystoseira were also removed in this way, but care was taken not to damage the organisms present on the substratum among these plants. Juveniles of Cystoseira that recruited during the experiment were removed with the same technique. Thus, the main treatment in this experiment had 3 levels: Cystoseira present $(\mathrm{CP})$, Cystoseira removed $(\mathrm{CR})$, and Cystoseira naturally absent (CA). There were 3 replicate shores within each treatment to estimate natural variability in the abundance of the response populations at the scale of (100s of km) (Fig. 1). CP and CR were located on different shores to be consistent with the proposed model that anthropogenic disturbance is the cause of the observed differences in assemblages at the scale of the shore. To test whether response of assemblages to the manipulation would change in relation to seasonal or other temporal patterns of species reproduction and recruitment, treatments were initiated in 2 different seasons (summer 1996 and winter 1997) and on 2 dates chosen randomly within each combination of shore $\times$ season. At each date, on those shores designated as $\mathrm{CR}$, four $2 \times 1 \mathrm{~m}$ patches were cleared of canopy algae and marked at their corners with epoxy-putty (Subcoat S, Veneziani) for relocation. Four $2 \times 1 \mathrm{~m}$ patches were also marked on the other shores and left undisturbed. The patches included in the experiment were selected randomly at the beginning of the study. Therefore, each shore comprised 16 patches $(2$ seasons $\times 2$ dates $\times 4$ patches at each date) distributed along 100 to $200 \mathrm{~m}$ stretches of coastline. The expected outcome of the manipulation was that $\mathrm{CR}$ assemblages diverged from $\mathrm{CP}$ assemblages, becoming progressively similar to those designated as CA. To test for temporal changes in the response of assemblages to the manipulation, organisms were sampled 4 and 18 mo after clearing. To obtain temporally independent data for analyses (see below), 2 of the 4 patches established on each shore at each date were chosen randomly and sampled after $4 \mathrm{mo}$, while the remaining 2 patches were sampled after 18 mo.
There were 2 main reasons for using patches of $2 \mathrm{~m}^{2}$ in this experiment. First, these areas were much larger than the largest organism in the assemblage (Cystoseira) making edge effects very unlikely. Second, because Cystoseira declines gradually in polluted areas (Benedetti-Cecchi pers. obs.), the resolution of the present experiment was appropriate for examining the response of assemblages to initial loss of canopy structure. The alternative, of removing Cystoseira from larger areas (e.g. whole shores) was logistically difficult and probably unethical.

Three $20 \times 20 \mathrm{~cm}$ plots were sampled randomly in each patch, avoiding a band about $30 \mathrm{~cm}$ wide along the margins. Cystoseira was removed before estimating the abundance of other organisms in CP. Abundances were estimated non-destructively either as percentage cover (algae and sessile invertebrates, with the exception of actinians) or as number of individuals plot $^{-1}$ (limpets and actinians). The percentage cover of each species or group of species was obtained as described above (see 'Sampling design').

Analysis of data. Patterns in abundance of Cystoseira and turf-forming algae in pristine and urban areas were compared graphically. Differences among locations in the time of sampling and in the number of sites, patches and replicates used, prevented a formal statistical analysis of the data. Despite these difficulties, we believe that the spatial and temporal interspersion of locations was still appropriate for contrasting pristine and urban areas (Table 1), and that the pattern in the data was clear enough to be interpreted from graphs.

Univariate and multivariate procedures were used to test hypotheses about the effects of removing Cystoseira. Multivariate procedures were used to compare assemblages among treatments for each season and age separately. Data were averaged across plots, patches and dates before analyses, to obtain a centroid for each shore in each combination of season, age and treatment. A matrix of similarities between each pair of shores was then calculated using the Bray-Curtis similarity coefficient (Bray \& Curtis 1957) on fourth root transformed data (Clarke 1993). This transformation was used to reduce differences in scale among variables, while preserving information about relative abundance of species among samples. Non-metric multidimensional scaling (nMDS) was used to produce 2-dimensional ordinations of the rank orders of similarities among shores in the different treatments (Field et al. 1982, Clarke 1993, Underwood \& Anderson 1994, Anderson \& Underwood 1997).

Further tests of multivariate responses to the manipulation of Cystoseira were done by calculating the percentage similarity between pairs of patches of different treatments, separately for each particular season and 


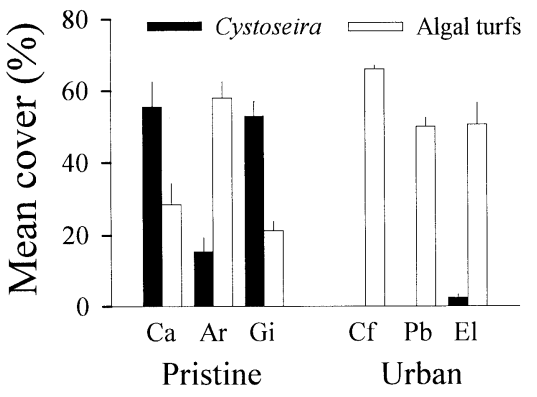

Fig. 2. Mean percentage cover ( $+\mathrm{SE}, \mathrm{n}=32$ to 60 ) of Cystoseira and turf-forming algae in pristine and urban locations. $\mathrm{Ca}=$ Capraia, $\mathrm{Ar}=$ Argentario, $\mathrm{Gi}=$ Giannutri, $\mathrm{Cf}=$ Calafuria, $\mathrm{Pb}=$ Punta Bianca, El = Elba

age. For this analysis, patches were pooled across shores and dates, so that there were 12 patches for each combination of treatment, season and age. Six patches from each treatment were then selected randomly and matched with 6 patches of another treatment. For example, to compare $\mathrm{CP}$ with the other treatments, 6 patches from CP were matched with 6 patches from $\mathrm{CR}$ and the remaining patches were matched with 6 patches from CA. Therefore, pairwise contrasts between treatments were obtained from 6 independent measures of similarity between patches in each case. This procedure was repeated for each particular season and age. The prediction was that the removal of Cystoseira should decrease the similarity between $\mathrm{CP}$ and $\mathrm{CR}$ and increase that between $\mathrm{CR}$ and CA. To test this prediction, and to determine whether effects changed in relation to season and age, a 3factor ANOVA was performed using the 6 independent measures of similarity as replicates (following Anderson \& Underwood 1997, Underwood \& Chapman 1998). The factors in this analysis were: contrast (3 levels, corresponding to the pairwise comparisons between treatments), season (2 levels) and age (2 levels). All factors were fixed in this analysis.

To identify important components of the assemblages, defined as those organisms that most contributed to the contrasts described above, the percentage contribution of each taxon to the average dissimilarity among treatments was calculated using SIMPER (Clarke 1993).

Finally, the individual responses of important taxa (defined as above) to the manipulation of Cystoseira were examined using a 6-factor mixed model ANOVA. The factors were: treatment (3 levels, fixed and orthogonal), shore (3 levels, random and nested within treatment), season (2 levels, fixed and orthogonal), date (2 levels, random and nested within each combination of shore $\times$ season),

age (2 levels, fixed and orthogonal), and patch (2 levels, random and nested within the interaction of age $x$ date). Data were log-transformed to homogenize variances (after Cochran's C-test). When appropriate, SNK tests were used for a posteriori comparisons of the means.

\section{RESULTS}

\section{Patterns in abundance of Cystoseira and turf-forming algae}

Cystoseira was always present in pristine locations and was dominant at Capraia and Giannutri, but the cover of canopy algae was less than $20 \%$ at Argentario where turf-forming algae were dominant (Fig. 2). In contrast, Cystoseira was absent in the urban areas at Calafuria and Punta Bianca and only a few clumps were observed at Elba. Turf-forming algae were always dominant in urban areas (Fig. 2). These data support the hypothesis that the percentage cover of Cystoseira and that of turf-forming algae were negatively correlated $(\mathrm{r}=-0.90, \mathrm{p}<0.05, \mathrm{n}=6)$.

Multivariate analyses. Assemblages were compared across treatments using nMDS ordination plots independently for each combination of season and age (Fig. 3). There were clear differences between CP and CA in these analyses, while the relationship between

- Canopy present $\bigcirc$ Canopy removed $\nabla$ Canopy absent

Summer / age 4

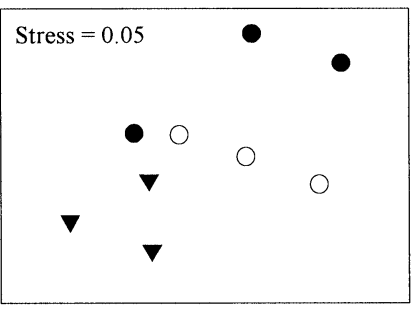

Winter / age 4

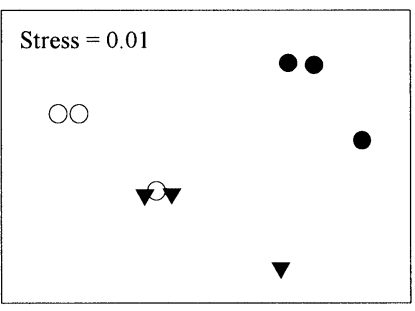

Fig. 3. Non-metric multidimentional scaling (nMDS) ordination plots comparing assemblages in the different treatments in-

dependently for each season and age

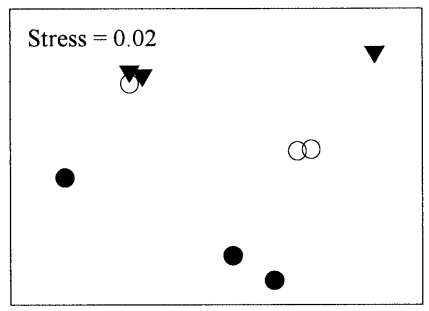

Winter / age 18

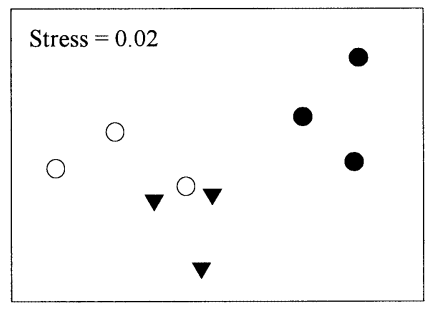


these treatments and CR changed in relation to season and age. Four mo after the start of the study, CR was intermediate between CP and CA for shores initiated in summer, while for shores initiated in winter CR was more similar to CA than to CP. After 18 mo, CR and CA tended to group separately from CP irrespective of the season when the experiment was initiated. Some differences between CR and CA were, however, still present at the end of the experiment (Fig. 3).

Comparisons of percentage similarity between pairs of patches of different treatments across seasons and ages showed that assemblages in CR were intermediate between those in CA and those in CP (Fig. 4). These patterns were indicated by the significant main effect of contrast in the analysis of variance on BrayCurtis measures of similarity $\left(\mathrm{MS}_{\mathrm{NUM}}=1161.1\right.$, $\left.\mathrm{MS}_{\mathrm{DEN}}=127.5, F_{2,60}=9.1, \mathrm{p}<0.0005\right)$, with the lowest similarity resulting when comparing $\mathrm{CP}$ with $\mathrm{CA}$. This similarity was significantly lower than that resulting from the other comparisons that did not differ significantly (i.e. the similarity between $\mathrm{CP}$ and CR was comparable to that between CA and CR; SNK test).

Several organisms contributed to the differences among treatments, and the relative importance of the different taxa changed between seasons and ages (Table 2). Despite this variability, the taxa that most discriminated among treatments included among algae articulated coralline and coarsely branched species

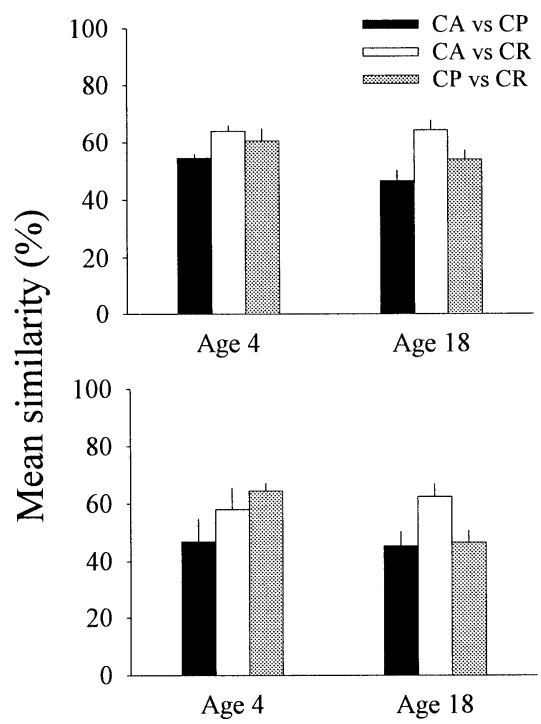

Fig. 4. Mean percentage similarity $(+\mathrm{SE}, \mathrm{n}=6)$ between pairs of treatments for (upper panel) summer and (lower panel) winter starts of the experiment. CR $=$ Cystoseira removed, $\mathrm{CP}=$ Cystoseira present, $\mathrm{CA}=$ Cystoseira naturally absent

Cystoseira compressa, filamentous and sheet-like algae and Valonia utricularis, and among invertebrates actinians, hydrozoans, mussels, sponges and vermetids. The specific responses of these organisms

Table 2. Percentage contribution to average dissimilarity among treatments. Values contributing to the first $50 \%$ of cumulative percentage for each treatment are in bold. $\mathrm{CP}=$ Cystoseira present, $\mathrm{CR}=$ Cystoseira removed, $\mathrm{CA}=$ Cystoseira naturally absent

\begin{tabular}{|c|c|c|c|c|c|c|c|c|c|c|c|c|}
\hline \multirow[b]{4}{*}{ Taxa } & \multicolumn{3}{|c|}{$\begin{array}{l}\text { Summer } \\
\text { Age } 1\end{array}$} & \multicolumn{3}{|c|}{$\begin{array}{l}\text { Summer } \\
\text { Age } 2\end{array}$} & \multicolumn{3}{|c|}{$\begin{array}{l}\text { Winter } \\
\text { Age } 1\end{array}$} & \multicolumn{3}{|c|}{$\begin{array}{l}\text { Winter } \\
\text { Age } 2\end{array}$} \\
\hline & CA & CA & $\mathrm{CP}$ & $\mathrm{CA}$ & CA & $\mathrm{CP}$ & $\mathrm{CA}$ & CA & $\mathrm{CP}$ & $\mathrm{CA}$ & CA & $\mathrm{Cp}$ \\
\hline & vs & vS & vs & vs & vs & vs & vs & vs & vS & vs & vs & vs \\
\hline & $\mathrm{CP}$ & $\mathrm{CR}$ & $\mathrm{CR}$ & $\mathrm{CP}$ & $\mathrm{CR}$ & $\mathrm{CR}$ & $\mathrm{CP}$ & $\mathrm{Cr}$ & $\mathrm{CR}$ & $\mathrm{CP}$ & $\mathrm{CR}$ & CR \\
\hline \multicolumn{13}{|l|}{ Algae } \\
\hline Articulated corallines & 5.6 & 7.0 & 5.9 & 8.8 & 11.0 & 6.5 & 7.4 & 8.4 & 6.3 & 7.3 & 11.0 & 10.0 \\
\hline Coarsely branched & 5.3 & 5.7 & 3.4 & 7.5 & 8.7 & 5.0 & 8.7 & 4.8 & 4.5 & 10.1 & 5.4 & 3.6 \\
\hline Crusts & 3.0 & 2.7 & 4.9 & 3.3 & 5.0 & 7.7 & 6.5 & 3.0 & 2.8 & 5.9 & 2.9 & 3.3 \\
\hline Cystoseira compressa & 6.0 & 8.3 & 9.9 & 8.6 & 9.1 & 10.0 & 10.8 & 5.8 & 6.6 & 10.1 & 5.2 & 5.4 \\
\hline Filamentous & 4.3 & 4.5 & 4.0 & 5.0 & 4.4 & 7.3 & 5.9 & 6.6 & 6.4 & 8.0 & 8.0 & 7.8 \\
\hline Padina pavonica & 0.0 & 4.3 & 5.9 & 2.8 & 4.5 & 7.5 & 4.5 & 2.0 & 0.0 & 5.6 & 0.0 & 2.6 \\
\hline Sheet-like & 5.3 & 11.7 & 10.5 & 7.1 & 7.5 & 11.0 & 9.6 & 5.1 & 6.1 & 10.2 & 4.4 & 5.4 \\
\hline Valonia utricularis & 8.2 & 7.8 & 2.8 & $\mathbf{7 . 0}$ & 6.3 & 3.9 & 0.0 & 4.7 & 4.7 & 2.3 & 4.5 & 4.7 \\
\hline \multicolumn{13}{|l|}{ Invertebrates } \\
\hline Actinians & 8.5 & 8.3 & 3.2 & 6.1 & 6.5 & 0.0 & 1.3 & 4.1 & 4.3 & 0.0 & 3.7 & 3.8 \\
\hline Ascidians & 2.2 & 0.0 & 2.7 & 1.2 & 0.0 & 1.9 & 2.7 & 4.4 & 4.4 & 2.6 & 5.0 & 5.0 \\
\hline Barnacles & 5.1 & 4.7 & 8.7 & 4.2 & 4.4 & 6.4 & 5.7 & 4.6 & 5.0 & 5.9 & 5.4 & 5.6 \\
\hline Bryzoans & 7.8 & 7.5 & 0.0 & 5.5 & 5.9 & 0.0 & 0.0 & 4.3 & 4.3 & 2.6 & 3.8 & 4.1 \\
\hline Hydrozoans & 6.5 & 6.1 & 8.5 & 6.6 & 6.4 & 6.5 & 6.6 & 9.3 & 10.1 & 0.6 & 8.6 & 9.0 \\
\hline Limpets & 7.7 & 0.0 & 9.6 & 3.4 & 1.6 & 5.9 & 5.2 & 5.7 & 6.0 & 6.4 & 3.3 & 3.7 \\
\hline Mussels & 3.4 & 2.4 & 2.1 & 3.5 & 2.1 & 4.8 & 9.1 & 9.4 & 8.0 & 11.4 & 7.6 & 6.7 \\
\hline Serpulids & 3.6 & 2.3 & 4.4 & 2.9 & 1.1 & 4.5 & 3.2 & 3.3 & 3.1 & 3.1 & 3.1 & 3.3 \\
\hline Sponges & 9.6 & 10.9 & 6.7 & 8.6 & 9.8 & 4.5 & 5.4 & 8.1 & 8.9 & 1.8 & 8.1 & 9.2 \\
\hline Vermetus & 6.2 & 5.9 & 5.3 & 7.8 & 5.6 & 5.6 & 6.5 & 6.4 & 6.1 & 5.4 & 7.9 & 6.6 \\
\hline
\end{tabular}


Table 3. Analysis of variance on mean percentage cover of articulate coralline algae. $\mathrm{Tr}=$ treatment, Se $=$ season, $\mathrm{A}=\mathrm{age}$

\begin{tabular}{|c|c|c|c|c|c|}
\hline Source of variation & df & MS & $F$ & $\mathrm{p}$ & Denominator for $F$ \\
\hline Treatment & 2 & 176.92 & 7.39 & $<0.05$ & Shore(Tr) \\
\hline Shore(Tr) & 6 & 23.96 & 7.04 & $<0.001$ & Date $($ Se $\times$ Shore $(\operatorname{Tr}))$ \\
\hline Season & 1 & 5.51 & 1.13 & $>0.3$ & Se $\times$ Shore $(\operatorname{Tr})$ \\
\hline $\operatorname{Tr} \times \mathrm{Se}$ & 2 & 1.48 & 0.30 & $>0.7$ & Se $\times$ Shore $(\operatorname{Tr})$ \\
\hline Se $\times$ Shore $(\operatorname{Tr})$ & 6 & 4.89 & 1.44 & $>0.25$ & Date $($ Se $\times$ Shore $(\operatorname{Tr}))$ \\
\hline Date $($ Se $\times$ Shore $(\operatorname{Tr}))$ & 18 & 3.40 & 2.36 & $<0.006$ & Patch $(\mathrm{A} \times$ Date $($ Se Shore $(\mathrm{Tr})))$ \\
\hline Age & 1 & 1.83 & 2.67 & $>0.1$ & A $\times$ Shore $(\operatorname{Tr})$ \\
\hline $\mathrm{A} \times \operatorname{Tr}$ & 2 & 10.45 & 15.27 & $<0.01$ & A $\times$ Shore $(\operatorname{Tr})$ \\
\hline A $\times$ Shore $(\operatorname{Tr})$ & 6 & 0.68 & 0.60 & $>0.7$ & A $\times$ Date $($ Se $\times$ Shore $(\operatorname{Tr}))$ \\
\hline $\mathrm{A} \times \mathrm{Se}$ & 1 & 0.40 & 0.44 & $>0.5$ & $\mathrm{~A} \times \mathrm{Se} \times$ Shore $(\operatorname{Tr})$ \\
\hline $\mathrm{A} \times \operatorname{Tr} \times \mathrm{Se}$ & 2 & 3.18 & 3.49 & $>0.05$ & A $\times$ Se $\times$ Shore $(\operatorname{Tr})$ \\
\hline $\mathrm{A} \times \mathrm{Se} \times \operatorname{Shore}(\operatorname{Tr})$ & 6 & 0.91 & 0.79 & $>0.5$ & A $\times$ Date $($ Se $\times$ Shore $(\operatorname{Tr}))$ \\
\hline A $\times$ Date $($ Se $\times$ Shore $(\operatorname{Tr}))$ & 18 & 1.15 & 0.80 & $>0.6$ & $\operatorname{Patch}(\mathrm{A} \times$ Date $(\mathrm{Se} \times$ Shore $(\operatorname{Tr})))$ \\
\hline $\operatorname{Patch}(\mathrm{A} \times$ Date $(\operatorname{Se} \times$ Shore $(\operatorname{Tr})))$ & 72 & 1.44 & 2.90 & $<0.0001$ & Residual \\
\hline Residual & 288 & 0.50 & & & \\
\hline Total & 431 & & & & \\
\hline
\end{tabular}

Table 4. Effects of treatments on mean percentage cover of algae. $\mathrm{Tr}=$ treatment, Se $=$ season, $\mathrm{A}=\mathrm{age} .{ }^{*} \mathrm{p}<0.05,{ }^{* *} \mathrm{p}<0.01$, ${ }^{* * *} \mathrm{p}<0.001$

\begin{tabular}{|c|c|c|c|c|c|c|c|c|c|c|c|}
\hline \multirow[b]{2}{*}{ Source of variation } & \multirow[b]{2}{*}{ df } & \multicolumn{2}{|c|}{$\begin{array}{c}\text { Coarsely } \\
\text { branched algae }\end{array}$} & \multicolumn{2}{|c|}{$\begin{array}{l}\text { Cystoseira } \\
\text { compressa }\end{array}$} & \multicolumn{2}{|c|}{$\begin{array}{c}\text { Filamentous } \\
\text { algae }\end{array}$} & \multicolumn{2}{|c|}{$\begin{array}{l}\text { Sheet like } \\
\text { algae }\end{array}$} & \multicolumn{2}{|c|}{$\begin{array}{l}\text { Valonia } \\
\text { utricularis }\end{array}$} \\
\hline & & MS & F & MS & $F$ & MS & $F$ & MS & $F$ & MS & $F$ \\
\hline Treatment & 2 & 126.76 & $6.13^{*}$ & 23.74 & 1.00 & 72.47 & $9.61^{*}$ & 27.80 & 3.69 & 19.89 & $6.20^{*}$ \\
\hline Shore(Tr) & 6 & 20.68 & $14.63^{* * *}$ & 23.84 & $9.33^{* * *}$ & 7.54 & 1.34 & 7.54 & $9.91^{* * *}$ & 3.22 & $3.60^{*}$ \\
\hline Season & 1 & 0.02 & 0.01 & 3.46 & 1.06 & 0.30 & 0.04 & 8.57 & 5.46 & 0.07 & 0.10 \\
\hline $\operatorname{Tr} \times \mathrm{Se}$ & 2 & 1.21 & 0.77 & 7.65 & 2.33 & 6.40 & 0.78 & 1.39 & 0.89 & 0.39 & 0.70 \\
\hline Se $\times$ Shore $(\operatorname{Tr})$ & 6 & 1.58 & 1.12 & 3.28 & 1.28 & 8.25 & 1.46 & 1.57 & 2.06 & 0.60 & 0.70 \\
\hline Date $($ Se $\times$ Shore $(\operatorname{Tr}))$ & 18 & 1.41 & $1.78^{*}$ & 2.56 & $2.43^{* *}$ & 5.63 & $4.75^{* * *}$ & 0.76 & 0.51 & 0.89 & $2.00^{*}$ \\
\hline Age & 1 & 0.56 & 0.43 & 0.96 & 0.80 & 0.51 & 0.71 & 0.01 & 0.00 & 0.19 & 0.40 \\
\hline $\mathrm{A} \times \operatorname{Tr}$ & 2 & 2.18 & 1.69 & ${ }^{\mathrm{a}} 4.34$ & 3.62 & 2.19 & 3.04 & 0.01 & 0.00 & 0.01 & 0.00 \\
\hline A $\times$ Shore $(\operatorname{Tr})$ & 6 & 1.29 & 0.43 & 1.20 & 0.99 & 0.72 & 0.17 & 2.79 & 1.16 & 0.46 & 0.50 \\
\hline $\mathrm{A} \times \mathrm{Se}$ & 1 & 0.01 & 0.01 & 1.02 & 1.88 & 1.02 & 1.07 & 1.02 & 0.68 & 0.04 & 0.10 \\
\hline $\mathrm{A} \times \operatorname{Tr} \times \mathrm{Se}$ & 2 & 3.88 & 2.18 & 6.971 & $12.85^{* *}$ & 3.83 & 4.02 & 1.10 & 0.74 & 0.41 & 0.60 \\
\hline $\mathrm{A} \times \mathrm{Se} \times$ Shore $(\operatorname{Tr})$ & 6 & 1.78 & 0.60 & 0.54 & 0.45 & 0.95 & 0.23 & 1.50 & 0.62 & 0.70 & 0.70 \\
\hline A $\times$ Date $($ Se $\times$ Shore $(\operatorname{Tr}))$ & 18 & 2.98 & $3.76^{* * *}$ & 1.22 & 1.16 & 4.21 & $3.55^{* * *}$ & 2.40 & 1.62 & 0.94 & $2.10^{*}$ \\
\hline $\operatorname{Patch}(\mathrm{A} \times$ Date $($ Se $\times$ Shore $(\operatorname{Tr})))$ & 72 & 0.79 & $1.53^{* *}$ & 1.05 & $1.92^{* * *}$ & 1.18 & $1.86^{* * *}$ & 1.48 & $2.71^{* * *}$ & 0.44 & $2.40^{* * *}$ \\
\hline Residual & 288 & 0.52 & 0.55 & 0.64 & 0.55 & 0.19 & & & & & \\
\hline Total & 431 & & & & & & & & & & \\
\hline
\end{tabular}

to the manipulation of Cystoseira are considered in detail below.

Univariate analyses. The removal of Cystoseira generally resulted in a significant increase in the abundance of algae, but whether this occurred as a main effect, or in interaction with other factors, depended on the specific group of algae considered. A detailed analysis of these effects for the articulated coralline algae is reported in Table 3. Results for other important taxa are summarised in Tables 4 and 5. The removal of Cystoseira significantly increased the percentage cover of the articulated coralline algae but the magnitude of this effect changed with age, resulting in a sig- nificant age $\times$ treatment interaction (Fig. 5A, Table 3). However, treatment means were ranked similarly by the SNK test at age 1 and age 2: CA > CR > CP. The interaction resulted because there was a larger difference between CA and CR at age 2 than at age 1, due to a natural increase in the abundance of articulated coralline algae in CA (Fig. 5A). The removal of Cystoseira also drastically increased the percentage cover of the coarsely branched algae, resulting in a significant main effect of treatment in the analysis (Fig. 5B, Table 4). These algae were significantly more abundant in CR than in the other treatments that did not differ significantly (SNK test). The percentage cover of 
Table 5. Effects of treatments on the mean abundance of invertebrates. Tr $=$ treatment, $\mathrm{Se}=$ season, $\mathrm{A}=\mathrm{age} .{ }^{*} \mathrm{p}<0.05,{ }^{* *} \mathrm{p}<0.01$, ${ }^{* * *} \mathrm{p}<0.001$

\begin{tabular}{|c|c|c|c|c|c|c|c|c|c|c|c|}
\hline \multirow[b]{2}{*}{ Source of variation } & \multirow[b]{2}{*}{ df } & \multicolumn{2}{|c|}{ Limpets } & \multicolumn{2}{|c|}{ Hydrozoans } & \multicolumn{2}{|c|}{ Mussels } & \multicolumn{2}{|c|}{ Sponges } & \multicolumn{2}{|c|}{ Vermetus spp. } \\
\hline & & MS & $F$ & MS & $F$ & MS & $F$ & MS & $F$ & MS & $F$ \\
\hline Treatment & 2 & 7.67 & 1.22 & 82.08 & 3.63 & 174.11 & 4.57 & 83.74 & $6.97^{*}$ & 79.79 & $7.96^{*}$ \\
\hline Shore(Tr) & 6 & 6.29 & $6.12^{* *}$ & 22.63 & $11.28^{* * *}$ & 38.11 & $21.80^{* * *}$ & 12.02 & $3.67^{*}$ & 10.03 & $10.74^{* * *}$ \\
\hline Season & 1 & 2.04 & $6.97^{*}$ & 14.60 & $13.09^{*}$ & 4.02 & 0.35 & 1.67 & $9.12^{*}$ & 0.37 & 0.19 \\
\hline $\operatorname{Tr} \times \mathrm{Se}$ & 2 & 0.25 & 0.87 & 0.83 & 0.75 & 0.85 & 0.07 & 5.99 & $32.70^{* * *}$ & 1.86 & 0.97 \\
\hline Se $\times$ Shore $(\operatorname{Tr})$ & 6 & 0.29 & 0.28 & 1.12 & 0.56 & 11.41 & $6.52^{* * *}$ & 0.18 & 0.06 & 1.93 & 2.06 \\
\hline Date $($ Se $\times$ Shore $(\operatorname{Tr}))$ & 18 & 1.03 & $3.27^{* * *}$ & 2.01 & $2.74^{* *}$ & 1.75 & 1.21 & 3.27 & $5.12^{* * *}$ & 0.93 & $1.77^{*}$ \\
\hline Age & 1 & 7.72 & 5.53 & 18.74 & 5.07 & 3.35 & 4.47 & 6.07 & $9.05^{*}$ & 0.30 & 0.29 \\
\hline $\mathrm{A} \times \operatorname{Tr}$ & 2 & 3.07 & 2.20 & 2.28 & 0.62 & 7.71 & $10.32^{*}$ & 0.32 & 0.47 & 2.87 & 2.81 \\
\hline $\mathrm{A} \times$ Shore $(\operatorname{Tr})$ & 6 & 1.40 & 2.33 & 3.69 & 1.85 & 0.75 & 0.57 & 0.67 & 0.66 & 1.02 & 0.65 \\
\hline $\mathrm{A} \times \mathrm{Se}$ & 1 & 0.02 & 0.05 & 6.30 & 5.65 & 0.00 & 0.00 & 0.49 & 0.38 & 0.35 & 0.19 \\
\hline $\mathrm{A} \times \operatorname{Tr} \times \mathrm{Se}$ & 2 & 0.38 & 1.16 & 1.63 & 1.46 & 0.19 & 0.51 & 1.15 & 0.89 & 0.12 & 0.07 \\
\hline $\mathrm{A} \times \mathrm{Se} \times$ Shore $(\operatorname{Tr})$ & 6 & 0.33 & 0.55 & 1.11 & 0.56 & 0.37 & 0.28 & 1.30 & 1.28 & 1.81 & 1.16 \\
\hline A $\times$ Date $($ Se $\times$ Shore $(\operatorname{Tr}))$ & 18 & 0.60 & $1.91^{*}$ & 1.99 & $2.72^{* *}$ & 1.32 & 0.92 & 1.01 & 1.58 & 1.56 & $2.96^{* * *}$ \\
\hline Patch $($ A $\times$ Date $($ Se $\times$ Shore $(\operatorname{Tr})))$ & 72 & 0.31 & $1.41^{*}$ & 0.73 & $1.81^{* * *}$ & 1.44 & $4.09^{* * *}$ & 0.64 & $1.68^{* *}$ & 0.53 & $1.74^{* * *}$ \\
\hline Residual & 288 & 0.22 & & 0.40 & & 0.35 & & 0.38 & & 0.30 & \\
\hline Total & 431 & & & & & & & & & & \\
\hline
\end{tabular}

the turf-forming alga Cystoseira compressa also increased where canopy algae were experimentally removed, but in this case patterns were not consistent across ages and seasons resulting in a significant age $\times$ treatment $\times$ season interaction (Fig. 5C, Table 4). The percentage cover of $C$. compressa was higher in CR than in the other treatments (that did not differ significantly) for clearances initiated in summer and sampled at age 2 (Fig. 5C, Table 4, SNK tests). In contrast, for all the other combinations of age and season, the SNK tests produced the following ranking of the means: CA $=\mathrm{CR}>\mathrm{CP}$. Conversely, there was a significant main effect of treatment for the filamentous algae (Fig. 5D, Table 4), with the SNK test producing the following ranking of the means: $\mathrm{CA}>\mathrm{CR}>$ CP. There was no significant difference among treatments in the percentage cover of the sheetlike algae, although a trend toward a larger abundance of these plants in CR was evident (Fig. 5E). In contrast to the other groups of algae analysed, the percentage cover of Valonia utricularis decreased in $\mathrm{CR}$ resulting in a significant main effect of treatment (Fig. 5F, Table 4). The following ranking of the means resulted from the SNK test: $\mathrm{CP}>\mathrm{CR}=\mathrm{CA}$.

There was no effect on limpets and hydrozoans from removing canopy algae, nor was there any difference in the abundance of these organisms between habitats with Cystoseira and those lacking a natural canopy of algae (Fig. 6A,B and Table 5). In contrast, mussels, sponges and vermetids all decreased in abundance where canopy algae were removed (Fig. 6C-E). Mussels were significantly more abundant in habitats lacking a natural canopy of Cystoseira than in habitats where canopy algae were present (Fig. 6C). The experimental removal of the canopy caused a decrease in the per-
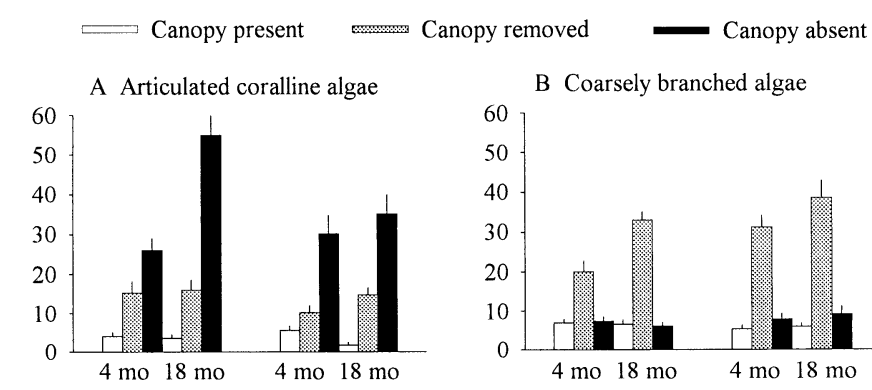

B Coarsely branched algae
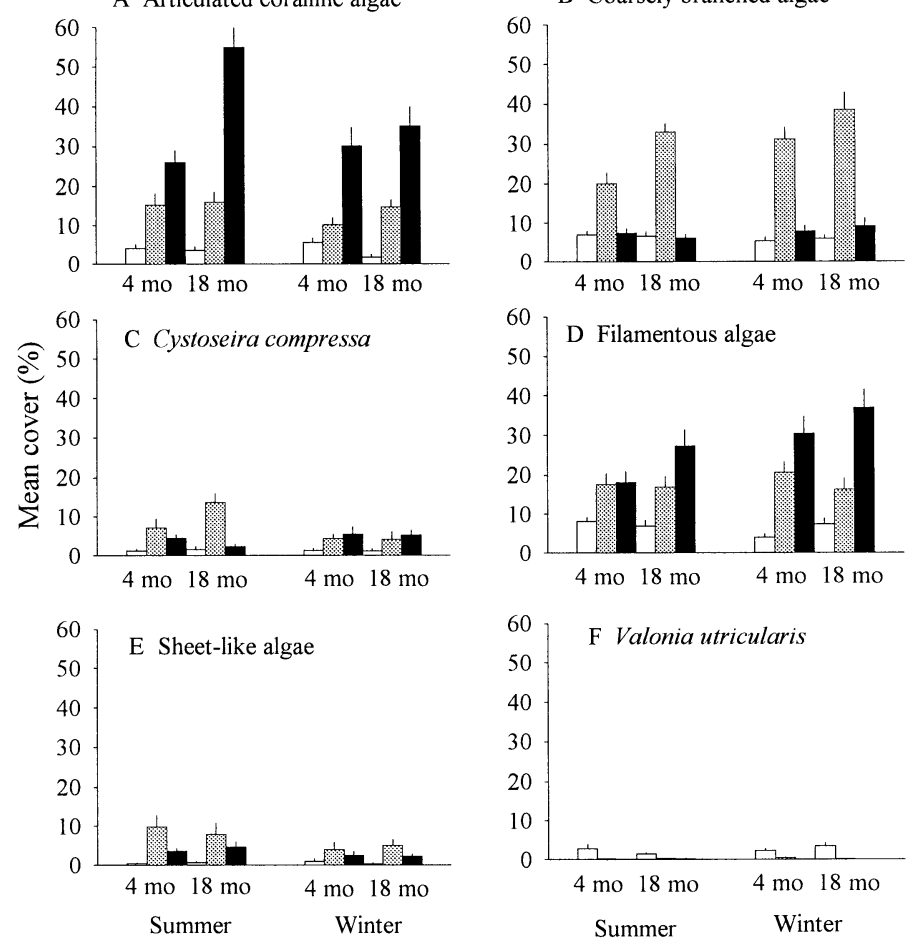

Fig. 5. Mean percentage cover of algae $(+\mathrm{SE}, \mathrm{n}=36)$ in the different treatments 4 and 18 mo after start of experiment 

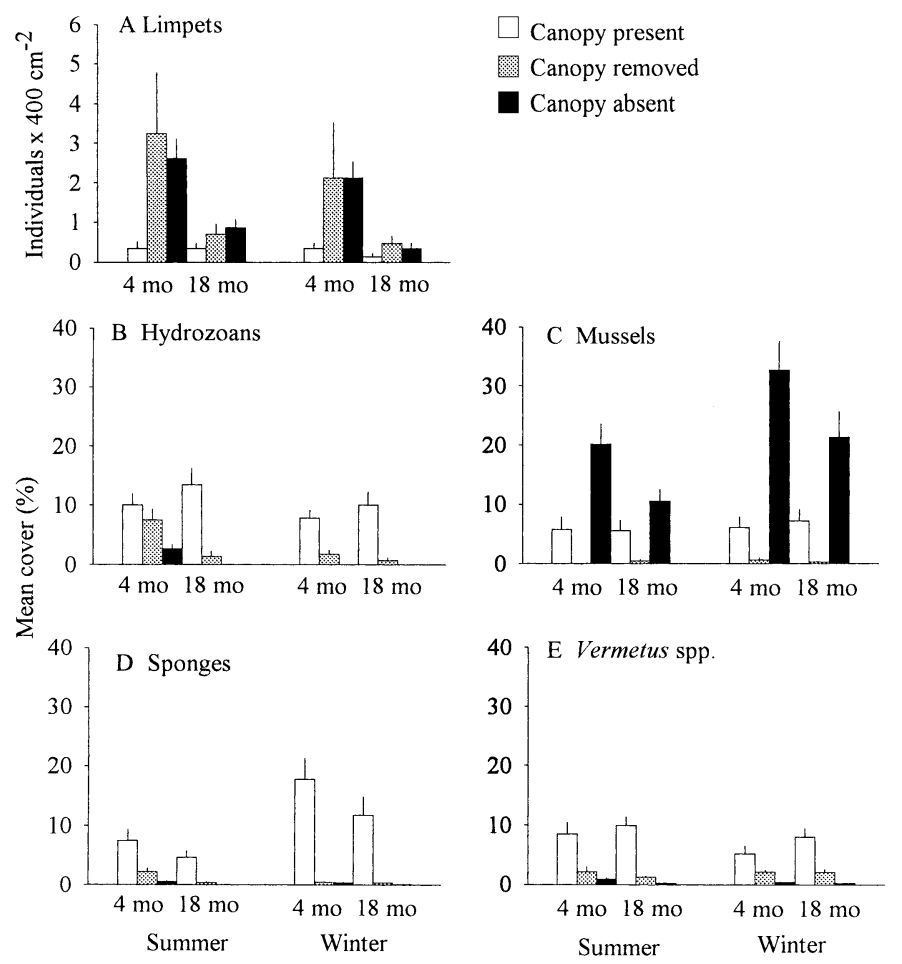

Fig. 6. Mean abundance of invertebrates $(+\mathrm{SE}, \mathrm{n}=36)$ in the different treatments 4 and 18 mo after start of experiment

centage cover of mussels, and differences among treatments were more evident for patches sampled at age 1 than at age 2 . This resulted in a significant age $\times$ treatment interaction (Table 5), but SNK tests done separately for each age produced once again a ranking of the means: $\mathrm{CA}>\mathrm{CP}>\mathrm{CR}$. The effects on sponges from removing Cystoseira differed from season to season, resulting in a significant treatment $\times$ season interaction (Table 5). The following ranking of the means was produced by the SNK test for treatments initiated in summer: $\mathrm{CP}>\mathrm{CR}>\mathrm{CA}$. Sponges were still significantly more abundant in CP than in the other treatments for clearings initiated in winter, but CR was not significantly different from $\mathrm{CA}$ in this season (i.e. $\mathrm{CP}>\mathrm{CR}=$ CA, SNK test). There was a significant main effect of treatment on vermetids, with a larger percentage cover of these organisms in CP than in the other treatments which did not differ significantly (Fig. 6E, Table 5 and SNK test).

Univariate analyses also revealed large and significant fluctuations in the abundance of macroalgae and invertebrates that were unrelated to the manipulation of Cystoseira, and were independent of natural differences between shores with canopy algae and those lacking canopy algae. Almost all the taxa analysed exhibited small-scale variability among patches, as well as large scale fluctuations in abundance among shores within treatments (Tables 4 \& 5). Several taxa exhibited significant age $\times$ date interactions, and significant differences between seasons occurred for hydrozoans and limpets. Seasonal changes were inconsistent across shores for mussels, resulting in a significant season $\times$ shore interaction (Table 5).

\section{DISCUSSION}

Numerous studies have shown significant changes in the structure of understory assemblages following removals of canopy algae (Dayton 1975, 1985, Schiel \& Foster 1986, Kennelly 1987, Johnson \& Mann 1988, Chapman 1990), but few have examined whether these changes reflect the effects of anthropogenic disturbances in coastal habitats. Here we have shown that $C y s-$ toseira was absent from most of the sites in urban areas in the northwest Mediterranean, while it was present and often dominant on shores in pristine locations. Removing the canopy enhanced the cover of turf-forming algae and decreased that of invertebrates commonly found in the understory of Cystoseira, leading to the development of the same type of assemblages as those found in urban areas. These results strongly support the proposition that urbanisation is the proximate cause of loss of Cystoseira in the Mediterranean, and that the disappearance of canopy algae causes an increase in cover of turf-forming species in disturbed habitats.

Removal of Cystoseira led to a decrease in the abundance of some understory organisms and to the establishment of an assemblage dominated by turf-forming algae. This suggests that relationships between Cystoseira and the structure of low-shore assemblages in the northwest Mediterranean involve both positive and negative interactions among organisms. Previous studies in aquatic systems have shown that direct positive interactions usually occur because some organisms ameliorate physical conditions in stressful habitats. Examples include interactions among vascular plants in salt marshes (Bertness \& Hacker 1994) and among algae in rocky intertidal habitats (Bertness \& Leonard 1997). Possibly, invertebrates and Valonia required the presence of Cystoseira because this alga provided shading and thus maintained damp conditions at low tide, or offered shelter and safer substratum for anchorage. Alternatively, Cystoseira might have been necessary to prevent invasion of turf-forming algae that would have covered and smothered the understory organisms otherwise. In this case, Cystoseira would have exerted a positive indirect effect resulting 
from a chain of 2 negative interactions: that of Cystoseira on turf-forming algae and that between these plants and understory species. Similar interactions have been described in other assemblages of canopy algae (Kastendiek 1982), and positive effects often involve indirect interactions in rocky shore habitats (Menge 1995, Benedetti-Cecchi 2000). Additional experiments are required to distinguish between these 2 alternatives.

There was a quick response of assemblages to the manipulation of Cystoseira. Menge (1997) and Strong (1997) have addressed the question of whether ecological experiments in rocky intertidal habitats are maintained long enough to detect direct as well as indirect effects, and examined the assumption that the latter would require more time than the former to become evident. These authors concluded that in most cases direct and indirect effects appear simultaneously and shortly after the beginning of the experiment (20 to $40 \%$ of total duration of experiments in Menge 1997). The results of the present study are consistent with these findings: drastic changes due to the removal of Cystoseira were already evident for most taxa after 4 mo. As discussed above, patterns were likely to be generated by direct as well as indirect interactions. The implication of these results is that any environmental impact on Cystoseira would cause drastic changes to the structure of low-shore assemblages in very short periods of time.

Other temporal patterns documented in this study included seasonal differences in the effects of Cystoseira on mussels and on the turf-forming alga Cystoseira compressa. Removing canopy algae had negative effects on mussels, despite these bivalves being more abundant on shores where canopy algae were naturally absent, and the effect was larger in winter than in summer. This probably reflected the fact that mussels anchored with their byssus to the bases of Cystoseira (e.g. Benedetti-Cecchi et al. 1996a). Patches of open space originated in the mussel matrix when these algae were removed, increasing the risk of dislodgement for the remaining animals during heavy storms in winter. In contrast, the removal of canopy algae increased the percentage cover of C. compressa and this effect was more evident in patches cleared in summer. This probably reflected seasonal patterns of recruitment of $C$. compressa. These plants were fertile from spring to summer at the study sites (authors' pers. obs.), so that the summer clearings coincided with the period of reproduction and recruitment of these plants which require open space to become established (e.g. Benedetti-Cecchi et al. 1996a).

The percentage cover of Cystoseira compressa in CR often matched values found in $\mathrm{CA}_{\text {, indicating that }}$ canopy algae accounted for much of the difference in the abundance of these plants between CP and CA. This occurred in 3 out of 4 combinations of season $\times$ age. In contrast, articulated coralline and filamentous algae, although increasing in abundance in $\mathrm{CR}$, never reached values found in habitats lacking natural canopy algae, while the coarsely branched algae became far more abundant in CR than in CA. These patterns were detected by the multivariate analyses, where some differences between assemblages in CR and CA still occurred by the end of the study. Although these treatments were characterised by the same groups of organisms, the relative abundance of some taxa was different.

Why was convergence between assemblages in CR and those in CA not completed by the end of the study? There are at least 2 possible explanations. First, complete convergence was not detected because the experiment did not run long enough. This alternative, although plausible, seems unlikely because most of the organisms that responded to the manipulation of Cystoseira were fast growing animals and plants, and 18 mo seems a reasonable period to observe responses in patterns of abundance for these assemblages. This conclusion is supported by the results of previous experiments indicating that disturbed assemblages of turf-forming algae converged to undisturbed ones within less than 1 yr in the northwest Mediterranean (Benedetti-Cecchi \& Cinelli 1994). Second, the shores supporting canopy algae might have been intrinsically different from those lacking these plants, in ways other than the presence or the absence of these algae. In general, the shores lacking natural populations of $\mathrm{Cys}$ toseira were close to urban areas and they were used here as a reference to represent disturbed habitats. They were not a random sample from the same population of shores that supported canopy algae. Therefore, the general environmental and biological settings differed between the 2 sets of shores and this might explain why there were differences in the relative abundance of some important taxa between CR and CA. For example, most of the turf-forming algae were articulate corallines in CA, while coarsely branched algae dominated in CR. These results are in agreement with the findings of other studies (Thom \& Widdowson 1978, Seapy \& Littler 1982, Airoldi et al. 1995), indicating that articulate corallines are generally more abundant than coarsely branched algae in the presence of anthropogenic disturbance.

In an attempt to fill the gaps between ecology as a scientific discipline and environmental management, Underwood (1995) stressed the need for new basic and strategic ecological research that is relevant to the process of problem-solving. He argued that one of the main reasons why ecologists and ecological theories are often unsuccessful in providing solutions to envi- 
ronmental issues is that most ecological investigations have been done at spatial and temporal scales different from those of anthropogenic disturbance. As a consequence, the resulting models and theories have little predictive power (see also Peters 1991 for problems with predictions in ecology). The issue of scale in ecology is well established, but it has been addressed mainly in the context of basic or 'natural' ecological processes (Dayton \& Tegner 1984, Wiens et al. 1993, Schneider 1994). In contrast, ecological research also needs to be done at those scales at which environmental impacts are expected to occur, to understand how human activities interact with basic ecological processes and to predict the consequences of these interactions. This problem has been recognised in some cases. For example, Thrush et al. (1998) investigated the relationship between changes in the structure of assemblages in soft sediment benthos and disturbance by commercial fishing at the scale of the fishery. This operated at the regional scale, dictating the appropriate spatial extent of the study.

Similarly, the spatial extent of the present study was dictated by the scale at which the process invoked to explain the differences in the structure of assemblages in low-shore habitats was thought to operate. Anthropogenic disturbance, and particularly sewage, has been invoked as a cause of the disappearance of Cystoseira from large areas of the coast (Hoffman et al 1988, Rodríguez-Prieto \& Polo 1996). By replicating the study on shores $(100 \mathrm{~s}$ of $\mathrm{km})$ apart, we were able to test whether there was a consistent response of assemblages to the experimental removal of Cystoseira over and above any intrinsic difference among shores, including small-scale variation due to natural disturbance, variable recruitment and biotic interactions (e.g. Benedetti-Cecchi et al. 1996a), and large-scale variability due to differences in climate and oceanographic conditions. Our results indicated that the effects of removing canopy algae were highly consistent across shores, providing an estimate of the sort of changes that might be expected due to the loss of canopy structure.

Collectively, our results support a cause-effect relationship between anthropogenic disturbance, loss of Cystoseira and dominance of turf-forming algae in urban areas of the northwest Mediterranean. The spatial and temporal consistency of these effects should increase confidence in predictions about the indirect consequences of disturbing canopy algae. Canopy algae are important habitat formers (sensu Jones et al. 1994), providing 3-dimensional complexity and interacting both positively and negatively with understory organisms. Thus, management options aimed at conserving these plants should simultaneously preserve other components of the assemblage. Management would benefit from a better understanding of the mechanisms by which anthropogenic disturbance affects Cystoseira. The identification of specific mechanisms may, however, be problematic if the observed patterns result from the interactive effects of different sources of stress. Despite these limitations, our analyses provided estimates of the expected response of Cystoseira to urbanisation and the effect size of Cystoseira on several components of the understory assemblage. These measures, together with the estimates of spatial and temporal variations of populations at different scales, can be used to design powerful environmental sampling programmes to detect human impacts in these systems (Fairweather 1991, Osenberg et al. 1994, Underwood 1994, Mapstone 1995, BenedettiCecchi in press).

Acknowledgements. We sincerely thank F. Micheli for substantial help with the manuscript. This work was supported by the EU under MAS-CT95-0012 Contract (EUROROCK), by a grant from the British Council and the Italian Ministry of the University, Scientific and Technological Research, and by a $60 \%$ research programme from the University of Pisa.

\section{LITERATURE CITED}

Addessi L (1994) Human disturbance and long-term changes on a rocky intertidal community. Ecol Appl 4:786-797

Airoldi L (1998) Roles of disturbance, sediment stress, and substratum retention on spatial dominance in algal turf. Ecology 79:2759-2770

Airoldi L, Rindi F, Cinelli F (1995) Structure, seasonal dynamics and reproductive phenology of a filamentous turf assemblage on a sediment influenced, rocky subtidal shore. Bot Mar 38:227-237

Anderson MJ, Underwood AJ (1997) Effects of gastropod grazers on recruitment and succession of an estuarine assemblage: a multivariate and univariate approach. Oecologia 109:442-453

Ballesteros E, Sala E, Garrabou J, Zabala M (1998) Community structure and frond size distribution of a deep water stand of Cystoseira spinosa (Phaeophyta) in the northwestern Mediterranean. Eur Phycol 33:121-128

Bellan-Santini D (1968) Conclusion d'un étude quantitative dans la biocénose des algues photophyles en Métiterranée sur le côtes de Provence. Mar Biol 1:250-256

Benedetti-Cecchi L (2000) Predicting direct and indirect interactions during succession in a midlittoral rocky shore assemblage. Ecol Monogr 70:45-72

Benedetti-Cecchi L (in press) Beyond BACI: optimization of environmental sampling designs through monitoring and simulation. Ecol Appl

Benedetti-Cecchi L, Cinelli F (1994) Recovery of patches in an assemblage of geniculate coralline algae: variability at different successional stages. Mar Ecol Prog Ser 110:9-18

Benedetti-Cecchi L, Nuti S, Cinelli F (1996a) Analysis of spatial and temporal variability in interactions among algae, limpets and mussels in low-shore habitats on the west coast of Italy. Mar Ecol Prog Ser 144:87-96

Benedetti-Cecchi L, Airoldi L, Abbiati M, Cinelli F (1996b) Estimating the abundance of benthic invertebrates: a comparison of procedures and variability between observers. Mar Ecol Prog Ser 138:93-101 
Bertness MD, Hacker SD (1994) Physical stress and positive associations among marsh plants. Am Nat 144:363-372

Bertness MD, Leonard GH (1997) The role of positive interactions in communities: lessons from intertidal habitats. Ecology 78:1976-1989

Borowitzka MA (1972) Intertidal algal species diversity and the effect of pollution. Aust J Mar Freshw Res 23:73-94

Boudouresque CF (1971) Contribution à l'étude phytosociologique des peuplements algaux des côtes varoises. Vegetatio 22:83-184

Bray JR, Curtis JT (1957) An ordination of the upland forest communities of Southern Wisconsin. Ecol Monogr 27: 325-349

Carpenter SR (1990) Large-scale perturbations: opportunities for innovation. Ecology 71:2038-2043

Carpenter SR, Chisholm SW, Krebs CJ, Schindler DW, Wright RF (1995) Ecosystem experiments. Science 269:324-327

Chapman ARO (1990) Effects of grazing, canopy cover and substratum type on the abundances of common species of seaweeds inhabiting littoral fringe tide pools. Bot Mar 1990:319-326

Chapman MG, Underwood AJ, Skiilleter GA (1995) Variability at different spatial scales between a subtidal assemblage exposed to the discharge of sewage and two control assemblages. J Exp Mar Biol Ecol 189:103-122

Clark JR (1996) Coastal zone management. CRC Press, Inc. Lewis Publishers, Boca Roton

Clarke KR (1993) Non-parametric multivariate analyses of changes in community structure. Aust J Ecol 18: 117-143

Dayton PK (1975) Experimental evaluation of ecological dominance in a rocky intertidal algal community. Ecol Monogr 45:137-159

Dayton PK (1985) Ecology of kelp communities. Annu Rev Ecol Syst 16:215-245

Dayton PK, Tegner MJ (1984) The importance of scale in community ecology: a kelp forest example with terrestrial analogs. In: Price PW, Slobodchikoff CN, Gand WS (eds) A new ecology: novel approaches to interactive systems. John Wiley \& Sons, p 457-481

Dethier MN, Graham ES, Cohen S, Tear LM (1993) Visual versus random-point percent cover estimations: 'objective' is not always better. Mar Ecol Prog Ser 96:93-100

Diez I, Secilla A, Santolaria A, Gorostiaga GM (1999) Phytobenthic intertidal community structure along an environmental pollution gradient. Mar Pollut Bull 38:463-472

Fairweather PG (1990) Sewage and the biota on seashores: assessment of impact in relation to nature variability. Environ Monit Assess 14:197-210

Fairweather PG (1991) Statistical power and design requirements for environmental monitoring. Aust J Mar Freshw Res 42:555-567

Feldmann J (1937) Recherces sur la végétation marine de la Méditerranée. La Côte des Albères, Wolf, Rouen

Field JC, Clarke KR, Warwick RM (1982) A practical strategy for analysing multispecies distribution patterns. Mar Ecol Prog Ser 8:37-52

Hoffman L, Clarisse S, Detienne X, Goffart A, Renard R, Demoulin V (1988) Evolution of the populations of Cystsoeira balearica (Phaeophyceae) and epiphitic Bangiophyceae in the Bay of Calvi (Corsica) in the last eight years. Bull Soc R Sci Liège 57:263-273

Johnson CR, Mann KH (1988) Diversity, patterns of adaptation, and stability of Nova Scotia kelp beds. Ecol Monogr 58:129-154

Jones CG, Lawton JH, Shachak M (1994) Organisms as ecosystem engineers. Oikos 69:373-386

Kastendiek J (1982) Competitor mediated coexistence: inter- actions among three species of benthic macroalgae. J Exp Mar Biol Ecol 62:201-210

Kennelly SJ (1987) Physical disturbances in an Australian kelp community. I. Temporal effects. Mar Ecol Prog Ser 40: 145-153

Keough MJ, Quinn GP (1998) Effects of periodic disturbances from trampling on rocky intertidal algal beds. Ecol Appl 8: 141-161

Likens GE (1985) An experimental approach for the study of ecosystems. J Ecol 73:381-396

Lindberg DR, Estes JA, Warheit KI (1998) Human influences on trophic cascades along rocky shores. Ecol Appl 8: 880-890

Littler MM, Murray SN (1975) Impact of sewage on the distribution, abundance and community structure of rocky intertidal macro-organisms. Mar Biol 30:277-291

Lubchenco J, Olson AM, Brubaker LB, Carpenter SR, Holland MM, Hubbell SP, Levin SA, MacMahon JA, Matson PA, Melillo JM, Mooney HA, Peterson CH, Pulliam HR, Real LA, Regal PJ, Risser PG (1991) The sustainable biosphere initiative: an ecological research agenda. Ecology 72: $371-412$

Mapstone BD (1995) Scalable decision rules for environmental impact studies: effect size, type I, and type II errors. Ecol Appl 5:401-410

Menge BA (1995) Indirect effects in marine rocky intertidal interaction webs: patterns and importance. Ecol Monogr 65:21-74

Menge BA (1997) Detection of direct versus indirect effects: were experiments long enough? Am Nat 149(5):801-823

Osenberg CW, Schmitt RJ, Holbrook SJ, Abu-Saba KE, Flegal AR (1994) Detection of environmental impacts: natural variability, effect size, and power analysis. Ecol Appl 4: $16-30$

Peters RH (1991) A critique for ecology. Cambridge University Press, Cambridge, UK

Peterson CH (1993) Improvement of environmental impact analysis by application of principles derived from manipulative ecology: lessons from coastal marine case histories. Aust J Ecol 18:21-52

Roberts DE, Smith A, Ajani P, Davis AR (1998) Rapid changes in encrusting marine assemblages exposed to anthropogenic point-source pollution: a 'beyond BACI' approach. Mar Ecol Prog Ser 163:213-224

Rodríguez-Prieto C, Polo L (1996) Effects of sewage pollution in the structure and dynamics of the community of Cystoseira mediterranea (Fucales, Phaeophyceae). Sci Mar 60: 253-263

Schiel DR, Foster MS (1986) The structure of subtidal algal stands in temperate waters. Oceanogr Mar Biol Annu Rev 24:265-307

Schindler DW (1987) Detecting ecosystem response to anthropogenic stress. Can J Fish Aquat Sci 44 (Suppl):6-25

Schmitt RJ, Osenberg CW (1996) Detecting ecological impacts: concepts and applications in coastal habitats. Academic Press, San Diego, USA

Schneider DC (1994) Quantitative ecology: spatial and temporal scaling. Academic Press, San Diego, USA

Schroeter SC, Dixon JD, Kastendiek J, Smith RO (1993) Detecting the ecological effects of environmental impacts: a case study of kelp forest invertebrates. Ecol Appl 3: 331-350

Seapy RR, Littler MM (1982) Population and species diversity fluctuations in a rocky intertidal community relative to severe aerial exposure and sediment burial. Mar Biol 71: $87-96$

Sousa WP, Schroeter SC, Gaines SD (1981) Latitudinal varia- 
tion in intertidal algal community structure: the influence of grazing and vegetative propagation. Oecologia 48: 297-307

Strong DR (1997) Quick indirect interactions in intertidal food webs. Trends Ecol Evol 12:173-174

Thom RM (1980) A gradient in benthic intertidal algal assemblages along the southern California coast. J Phycol 16: 102-108

Thom RM, Widdowson TB (1978) A resurvey of E. Yale Dawson's 42 intertidal algal transects on the southern California mainland after 15 years. Bull So Calif Acad Sci $77: 1-13$

Thrush SF, Hewitt JE, Cummings VJ, Dayton PK, Cryer M, Turner SJ, Funnell GA, Budd RG, Milburn CJ, Wilkinson MR (1998) Disturbance of the marine benthic habitat by commercial fishing: impacts at the scale of the fishery. Ecol Appl 8:866-879

Underwood AJ (1992) Beyond BACI: the detection of environmental impacts on populations in the real, but variable, world. J Exp Mar Biol Ecol 161:145-178

Underwood AJ (1994) On beyond BACI: sampling designs that might reliably detect environmental disturbances. Ecol Appl 4:3-15

Editorial responsibility: Otto Kinne (Editor),

Oldendorf/Luhe, Germany
Underwood AJ (1995) Ecological research and (and research into) environmental management. Ecol Appl 5:232-247

Underwood AJ, Anderson MJ (1994) Seasonal and temporal aspects of recruitment and succession in an intertidal estuarine fouling assemblage. J Mar Biol Assoc UK 74: 563-584

Underwood AJ, Chapman MG (1998) A method for analysing spatial scales of variation in composition of assemblages. Oecologia 117:570-578

Vogt H, Schramm W (1991) Conspicuous decline of Fucus in Kiel Bay (Western Baltic): what are the causes? Mar Ecol Prog Ser 69:189-194

Wiens JA, Stenseth NC, Van Horne B, Ims RA (1993) Ecological mechanisms and landscape ecology. Oikos 66: 369-380

Worm B, Lotze HK, Engkvist R, Labanauskas V, Sommer U (1999) Marine diversity shift linked to interactions among grazers, nutrients and propagule banks. Mar Ecol Prog Ser 185:309-314

Worm B, Lotze HK, Sommer U (2000) Coastal food web structure, carbon storage, and nitrogen retention regulated by consumer pressure and nutrient loading. Limnol Oceanogr 45:339-349

Submitted: June 23, 2000; Accepted: October 6, 2000

Proofs received from author(s): March 22, 2001 